\title{
Exercise - A unique endogenous regulator of irisin, BDNF, leptin and cortisol against depression
}

Authors' Contribution: A Study Design

B Data Collection

C Statistical Analysis

D Data Interpretation

E Manuscript Preparation

F Literature Search

G Funds Collection

\author{
Gilmara Gomes de Assis ${ }^{\mathrm{ABD}}$, Paweł Cięszczyk ${ }^{\mathrm{ABD}}$ \\ Gdansk University of Physical Education and Sport, Gdansk, Poland
}

abstract

Depression is the most prevalent stress-related disorder affecting the population world-wide with potential for an eminent increase after the 2020 pandemic. The mechanisms through which metabolism is involved in depression and stress disorders have been extensively investigated. However, their assessment using exogenous measures is a current limitation. Exercise, as is well reported in animal studies, exerts a critical regulatory influence on the main factors known to participate in these mechanisms. This overview describes the role of cortisol, leptin, irisin and BDNF in the exercise physiology and the known mechanism through which these factors act in anti-depressant mechanisms. Furthermore, the exercise is proposed as a clinical recommendation due to its effective and affordable character in treating depression for the sustainability of public health.

Key words: leptin, irisin, BDNF, metabolism, obesity.

\section{article details}

Article statistics: Word count: 2,051; Tables: 0; Figures: 0; References: 76

Received: October 2020; Accepted: November 2020; Published: December 2020

Full-text PDF: http://www.balticsportscience.com

Copyright $\odot$ Gdansk University of Physical Education and Sport, Poland

Indexation: Celdes, Clarivate Analytics Emerging Sources Citation Index (ESCI), CNKI Scholar (China National Knowledge Infrastructure), CNPIEC, De Gruyter - IBR (International Bibliography of Reviews of Scholarly Literature in the Humanities and Social Sciences), De Gruyter - IBZ (International Bibliography of Periodical Literature in the Humanities and Social Sciences), DOAJ, EBSCO - Central \& Eastern European Academic Source, EBSCO - SPORTDiscus, EBSCO Discovery Service, Google Scholar, Index Copernicus, J-Gate, Naviga (Softweco, Primo Central (ExLibris), ProQuest - Family Health, ProQuest - Health \& Medical Complete, ProQuest - Illustrata: Health Sciences, ProQuest - Nursing \& Allied Health Source, Summon (Serials Solutions/ProQuest, TDOne (TDNet), Ulrich's Periodicals Directory/ulrichsweb, WorldCat (OCLC)

Funding: This research received no specific grant from any funding agency in the public, commercial, or not-for-profit sectors.

Conflict of interests: Corresponding author:

Open Access License: Authors have declared that no competing interest exists.

Gilmara Gomes de Assis, Gdansk University pf Physical Education and Sport, Kazimierza Górskiego 1, 80-336 Gdansk, Poland; e-mail: gilmara.gomesdeassis@awf.gda.pl

This is an open access article distributed under the terms of the Creative Commons Attribution-Non-Commercial-NoDerivatives 4.0 International (https://creativecommons.org/licenses/by-nc-nd/4.0/), which permits use, distribution and reproduction in any medium, provided the original work is properly cited, the use is non-commercial and is otherwise in compliance with the license. 


\section{INTRODUCTION}

In 2008, the World Health Organization projected that depression would rank as the first cause of burden of disease by 2030 . The disease onset is inherently unpredictable, and the duration of episodes, the number of episodes over a lifetime, and the pattern in which they occur are variable. However, the recurrence of depression is high, and its risk increases with every episode. Yet, each episode and the outcome is less favorable with older age [1]. Reports from nine months since the outbreak of the current Covid-19 pandemic in 2020 show a substantial increase in depression and its related disorders, such as sleeplessness, anxiety, post-traumatic stress symptoms, and preexisting psychiatric disorders, all over the globe [2-5]. Facing this global crisis, with unprecedented repercussions in the healthcare systems, policies of preventative care, which are considerably less explored, seem to be a relevant solution for economies both with higher incomes and lower incomes $[6,7]$.

Initially, considered as therapeutic for cardiorespiratory conditions [8,9], the known benefits of exercise, beyond esthetics or performance, have expanded to a side support for treatment of obesity and depression. Depression is clinically characterized by atrophy or impairment in the functioning of cortico-limbic neuronal circuits that affect the regulation of mood and emotion [10-12]. Physiologically, the onset of depression is associated with a malfunction in the hypothalamus-pituitary-adrenal (HPA) axis and excessive cortisol levels [13]. By contrast, a regular practice of exercise is associated to a 'stabilizing effect' on the symptoms and progression of the depression condition and has been observed to positively affect response to its treatment $[14,15]$.

Hormones and cytokines converge in the physiological control of exercise and stress. Briefly, the corticotropin-releasing hormone released by the hypothalamus in response to a metabolic stress (a psychologically-derived metabolism response) induces adrenocorticotropin secretion which stimulates secretion of cortisol from adrenal cortex cells. Lower cortisol levels signal through membrane-associated receptors and second messengers (or nongenomic pathways), while high concentrations of cortisol bind to glucocorticoid receptor (GR) within the cell cytoplasm to initiate, in the nucleus, the expression of a groups of glucocorticoid-responsive genes that are involved in several metabolic functions under the regulation of transcription factors [16]. The chronic exposure to stressful events and high cortisol loads likely result in a GR resistance which, in turn, interferes with the appropriate regulation of inflammation. Therefore, stress and GR resistance conditions result in an HPA down-regulation of local proinflammatory cytokine response, which is the main risk factor for depression and stress-related metabolic disorders [17].

Key cytokines synergistically involved in the cell response to stress have been intensively investigated for their critical roles in the central mechanisms of depression and metabolic disorders. Reports on the role of brain-derived neurotrophic factor (BDNF) and irisin, which are produced by muscle and neuronal tissues, and on leptin, which is secreted by adipocytes under metabolic stress conditions, place these proteins as axil molecules for the understanding of the link between metabolism and the brain. Secreted leptin can cross the blood brain barrier (BBB) where in the brain, leptin binds to leptin receptors present in several thalamic, hypothalamic and midbrain regions that are associated with depression and energy homeostasis [18]. While irisin secreted by muscles and neural tissue has been demonstrated to play a role in depression disorders that are associated with obesity and metabolic syndrome $[19,20]$. Finally BDNF, the main neurotrophin produced in the adult brain whose signal transduction is essential for neuroprotection and plasticity [21, 22], has been extensively studied for metabolic features [23, 24].

Not by coincidence, these proteins have been frequently targeted in research on therapeutic approaches. However, following the example of cortisol, the complexity and tight local 
regulation of these cytokines represent an end line for the attempts of an exogenous manipulation [24-27]. Whereas the mechanisms associating depression and metabolic disorders are less clear, the systems underlying the onset of depression undeniably include cortisol dynamics, which is fundamentally involved in a systemic regulation of the above mentioned cytokines time-response and tissue-specific synthesis [28-30].

In a preventative perspective, it is reasonable to suggest that a physiological approach to the treatment of depression - regarding the exercise-induced endogenous regulation of these factors - is a feasible alternative for the sustainability of policies on public healthcare. Here, we will describe the physiological effects of the exercise metabolism on regulation of irisin, $\mathrm{BDNF}$ and leptin, and elucidate the neurobiological mechanisms by which the regulation of these factors affects depression disorders with a potential for prevention and treatment.

\section{EXERCISE METABOLISM AND THE PHYSIOLOGICAL ROLE OF LEPTIN, IRISIN AND BDNF}

Moving from resting to exercise states, there is an increase in the amount of energy demand by cells and speed of chemical reactions that provide this energy out of the assimilation of nutrient's substrates - also known as the metabolic rate (MR). This is possible due to a sympathoadrenal response with a rapid increase in the release of epinephrine in support of the ventilation demand. The acute rise of epinephrine then immediately elevates the heart rate and circulating blood pressure enhancing oxygen delivery to the requesting tissues [31]. Of the substrates available for the aerobic energy metabolism, glucose (GLU) is the most profitable and fast, and also the primary source required for the brain's supply. In the cells under normal aerobic conditions, GLU goes through nine enzymatic reactions to produce pyruvate which is converted into acetylcoenzyme A that proceeds to oxidation inside mitochondria through a cycle chain of chemical reactions known as the Krebs cycle. As a result, cellular energy in the form of adenosine triphosphate (ATP) is produced while residual carbon dioxide is transported into the blood [32]. To a certain MR range, the cells can plead for the oxidation of glycogen and fatty acids as alternative sources as well, taking into account several intracellular events [33]. Whenever the oxygen is insufficient, pyruvate can be converted into lactate by one additional enzymatic reaction $[34,35]$. Sidewise accumulated lactate thus is released into the circulation where it can be transported to the liver and goes through gluconeogenesis, or else it may cross the BBB and reach the neural tissue where it is also converted to pyruvate and enter the Krebs cycle. Lactate uptake by the brain might increase more than 2 -fold from rest to exercise states [36].

Increase in the activity of 5' adenosine monophosphate-activated protein kinase (AMPK), a central enzyme involved in the oxidation cascades of GLU, glycogen and fatty acid, leads to induction of the expression of the co-transcription activator proliferator-activated receptor gamma coactivator 1-alpha (PGC-1 $\alpha$ ) via direct phosphorylation [37]. PGC-1 $\alpha$ co-activates transcription factors that regulate the expression of several nuclear genes including FNDC5 and BDNF and those involved in the mitochondrial genesis and DNA duplication. Since that expression of mitochondrial genes also responds to metabolic stressinduced PGC1- $\alpha$ activity, this 'reward effect' enables an immediate response and a long lasting adaption against oxidative stress and degradation [38,39]. PGC-1 $\alpha$ upregulation also mediates the acute blood pressure-induced vasodilatory boost and is involved the microvascular adaptions to exercise [40].

First identified as a PGC1- $\alpha$-dependent cytokine, FNDC5 named after the gene FNDC5, is cleaved and secreted from muscle cells as irisin and acts preferentially on subcutaneous 
fat tissue through an increase in the adipocytes expression of thermogenesis-related genes. While a specific receptor for irisin has not been discovered, its activity-dependent effects of irisin have also been observed in the bone tissue through the promotion of skeletal remodeling via integrin receptors. The autocrine and paracrine actions of irisin confer an inhibitory effect on adipogenesis [41-43]. Conversely, the neuronal expression of BDNF in response to metabolic stress is also associated to the PGC1- $\alpha$ /FNDC5 pathway [44-46]. BDNF plays multiple roles in the activity-dependent regulation of neuronal synapses structure and function. The mechanism by which BDNF expression and signaling promotes neurogenesis, synaptogenesis, long-term potentiation directly influence on memory, executive function and other cognitive processes have been greatly reported [21,47-49]. In exercise, the circulating levels of BDNF, whose main source is attributed to the brain, increase in accordance to demands on aerobic metabolism [50-52].

Meanwhile, a pulsatile release and well-synchronized tonic increase in cortisol levels occurs along with the metabolic stress, which then penetrates into the cells binding to glucocorticoid receptors within the cytoplasm, in a complex that translocates to the nucleus and starts catabolic and anti-anabolic actions by regulating expression of specific genes [53]. The actions of cortisol revolve around providing a pool of free branched chain amino acids that are used either as building blocks for the synthesis of the ultimately needed proteins expressed during metabolic stress or as an additional substrate for oxidation. All of which thus inhibits inflammation. Such process remains up to the recovery period ensuring the destruction of physiologically exhausted protein structures in order to make possible their substitution by newly synthesized ones [54].

Finally, secreted by adipocytes, an increase in the circulating levels of leptin during the exercise serves as a signal report of the energetic reserves status to the CNS and occurs in an inverse proportion to the fitness conditions. Leptin activation of the long form of leptin receptor located especially in the hypothalamus, midbrain and brainstem is thus considered a mechanism of central control of the energy homeostasis [55]. Increases in leptin levels ultimately regulate the food intake and energy storage, whereas the serum levels of leptin correlate with the individual's body fat mass [56-59].

\section{THE ANTI-DEPRESSANT EFFECT OF THE EXERCISE}

Research on neurobiology of exercise and experimental models have helped to build the knowledge on the importance of an endogenous regulation of factors with critical roles in the mechanisms involved in the physiology of stress and depression that still have been a challenge for pharmacologic approaches. Experimental reports suggest that a decrease in leptin receptors which are found in subcortical structures of the brain involved in the limbic system, associated with increased activation of the HPA axis can lead to an obesityrelated depression disorder [26, 60]. Consistently, an increase in leptin levels as a reflection of leptin receptors resistance, gathered with an uncontrolled eating, is observed in obese and overweight subjects that display inflammatory states [61]. On the other hand, the role of leptin in neuronal growth in association with BDNF has been pointed as a positive effect of leptin signaling in these brain regions $[18,62]$. For instance, BDNF-deficient animals present obesity and cognitive impairment which can be reversed by exercise through an improvement in leptin sensitivity induced synaptic plasticity [55]. Furthermore, in welltrained individuals who display of physiological levels of leptin lower than the average range, these levels are more stable in accordance to the fitness conditions [56, 58].

Similarly, increases in cortisol levels with consequent glucocorticoid receptors (GR) resistance is a common cause of stress-induced depression. While leptin appears to be able to reverse some of the negative effects of GR resistance $[63,64]$, the excessive cortisol- 
induced GR resistance implicates in different types of depression and a variety of stressrelated disorders [65-67]. Moreover, the down-regulation of GR signaling observed in stress disorders is associated with impairment in the downstream cascades of BDNF signaling which interferes in the neuronal capability of plasticity (as reviewed by De Assis and Gasanov, 2019 [68]). It is conclusive that a critical endogenous balance in the circulating levels of both leptin and cortisol is essential for their delivery of pro-neuroplasticity and homeostasis control actions, which are the key elements linking metabolism and stressrelated disorders.

Additionally, the exercise-induction of irisin and BDNF expression via up-regulation of PGC1- $\alpha$ has shown to modulate neuroplasticity in the hippocampal and cortex areas as an anti-depressant effect $[69,70]$. Optimal levels of these two cytokines are thus associated with neuroprotection and preservation against cognitive decline [71-73]. Specifically for depression, the exercise-induced increases in BDNF helps as a generic contributor to neuronal plasticity affecting the related brain regions in a morphological and functional manner [74-76].

\section{CONCLUSION}

Considering the advances in explaining the molecular mechanisms connecting the brain and the body metabolism into an integrated system in the development of mental and metabolic illness. Furthermore, recognizing the practical limitations of an exogenous regulation of this integrate system, it seems to be the time to assume exercise as a clinical recommendation for depression and various stress-induced disorders, as a way of minimizing the overburden of the primary healthcare system. This overview suggests inclusion of exercise as a prescription in the guidance protocols for the patients with depression and stress-related metabolic disorders.

\section{REFERENCES}

[1] Malhi GS, Mann JJ. Depression. Lancet. 2018;392:2299-2312. https://doi.org/10.1016/S0140-6736(18)31948-2

[2] Vindegaard N, Benros ME. COVID-19 pandemic and mental health consequences: Systematic review of the current evidence. Brain, Behavior, and Immunity. 2020;89:531-542. https://doi.org/10.1016/j.bbi.2020.05.048

[3] Ozamiz-Etxebarria N, Dosil-Santamaria M, Picaza-Gorrochategui M, Idoiaga-Mondragon N. Stress, anxiety, and depression levels in the initial stage of the COVID-19 outbreak in a population sample in the northern Spain. Cad. Saude Publica. 2020;36. https://doi.org/10.1590/0102-311x00054020

[4] Özdin S, Bayrak Özdin Ş. Levels and predictors of anxiety, depression and health anxiety during COVID-19 pandemic in Turkish society: The importance of gender. Int J Soc Psychiatry. 2020;66:504-511. https://doi. org/10.1177/0020764020927051

[5] Torales J, O’Higgins M, Castaldelli-Maia JM, Ventriglio A. The outbreak of COVID-19 coronavirus and its impact on global mental health. Int J Soc Psychiatry. 2020;66:317-320. https://doi.org/10.1177/0020764020915212

[6] Ivanková V, Kotulič R, Gonos J, Rigelský M. Health care financing systems and their effectiveness: An empirical study of OECD countries. Int J Environ Res Public Health. 2019;16(20):3839. https://doi.org/10.3390/ijerph16203839

[7] Wang F. The roles of preventive and curative health care in economic development. PLoS One. 2018;3. https://doi. org/10.1371/journal.pone.0206808

[8] Faulkner AB. On the degree to which exercise should be carried in some varieties of dyspepsia. Edinb Med Surg J. 2, 5-8 (1806).

[9] Johnson \& Seneca. On the Curative Effects of Carriage and Travelling Exercise. Medico-chirurgical Rev. 10, 519524 (1829).

[10] Aliev G, Beeraka NM, Nikolenko VN, et al. Neurophysiology and psychopathology underlying PTSD and recent insights into the PTSD therapies - A comprehensive review. J Clin Med. 2020;9:2951. https://doi.org/10.3390/jcm9092951

[11] Rajkowska G, Miguel-Hidalgo J. Gliogenesis and glial pathology in depression. CNS Neurol Disord. - Drug Targets. 2008;6:219-233. https://doi.org/10.2174/187152707780619326

[12] Levy MJF, Boulle F, Steinbusch HW, van den Hove DLA, Kenis G, Lanfumey L. Neurotrophic factors and neuroplasticity pathways in the pathophysiology and treatment of depression. Psychopharmacology. 2018;235:2195-2220. https:// doi.org/10.1007/s00213-018-4950-4

[13] Spencer RL, Deak T. A users guide to HPA axis research. Physiology and Behavior. 2017;178:43-65. https://doi. org/10.1016/j.physbeh.2016.11.014 
[14] Heyman E, Gamelina FX, Goekint M, et al.Intense exercise increases circulating endocannabinoid and BDNF levels in humans-Possible implications for reward and depression. Psychoneuroendocrinology. 2012;37:844-851. https:// doi.org/10.1016/j.psyneuen.2011.09.017

[15] Beserra AHN, Kameda P, Deslandes AC, Schuch FB, Laks J, Sales de Moraes H. Can physical exercise modulate cortisol level in subjects with depression? A systematic review and meta-analysis. Trends Psychiatry Psychother 2018;40:360-368. https://doi.org/10.1590/2237-6089-2017-0155

[16] Rhen T, Cidlowski JA. Antiinflammatory action of glucocorticoids - New mechanisms for old drugs. N Engl J Med. 2005;353:1711-1723. https://doi.org/10.1056/NEJMra050541

[17] Cohen S, Janicki-Deverts D, Doyle WJ, et al. Chronic stress, glucocorticoid receptor resistance, inflammation, and disease risk. Proc Natl Acad Sci USA. 2012;109:5995-5999. https://doi.org/10.1073/pnas.1118355109

[18] Ge T, Fan J, Yang W, Cui R, Li B. Leptin in depression: a potential therapeutic target. Cell Death Dis. 2018;9:1096. https://doi.org/10.1038/s41419-018-1129-1

[19] Hofmann T, Elbelt U, Ahnis A, et al. The exercise-induced myokine irisin does now show an association with depressiveness. J Physiol. Pharmacol. 2016Apr;67(2):195-203.

[20] Huh JY, Panagiotou G, Mougios V, et al. FNDC5 and irisin in humans: I. Predictors of circulating concentrations in serum and plasma and II. mRNA expression and circulating concentrations in response to weight loss and exercise. Metabolism. 2012;61: 1725-1738. https://doi.org/10.1016/j.metabol.2012.09.002

[21] Panja D, Bramham CR. BDNF mechanisms in late LTP formation: A synthesis and breakdown. Neuropharmacology. 2014;76:664-676. https://doi.org/10.1016/j.neuropharm.2013.06.024

[22] Leal G, Comprido D, Duarte CB. BDNF-induced local protein synthesis and synaptic plasticity. Neuropharmacology. 2014;76:639-656. https://doi.org/10.1016/j.neuropharm.2013.04.005

[23] Dinoff A, Herrmann N, Swardfager W, et al, The effect of exercise training on resting concentrations of peripheral brain-derived neurotrophic factor (BDNF): A meta-analysis. PLoS One. 2016;11:e0163037. https://doi.org/10.1371/ journal.pone.0163037

[24] de Assis GG., Gasanov EV, de Sousa MBC, Kozacz A, Murawska-Cialowicz E. Brain derived neutrophic factor, a link of aerobic metabolism to neuroplasticity. J Physiol Pharmacol. 2018;69:351-359.

[25] Arhire LI, Mihalache L, Covasa M. Irisin: A hope in understanding and managing obesity and metabolic syndrome. Front Endocrinol. (Lausanne). 2019;10:524. https://doi.org/10.3389/fendo.2019.00524

[26] Liu W, Liu J, Xia J, et al. Leptin receptor knockout-induced depression-like behaviors and attenuated antidepressant effects of exercise are associated with STAT3/SOCS3 signaling. Brain Behav Immun. 2017;61:297-305. https://doi. org/10.1016/j.bbi.2017.01.001

[27] Sasi M. Vignoli B, Canossa M, Blum R. Neurobiology of local and intercellular BDNF signaling. Pflugers Arch Eur J Physiol. 2017;469:1-18. https://doi.org/10.1007/s00424-017-1971-5

[28] Hill EE, Zack E, Battaglini C, Viru M, Viru A, Hackney AC. Exercise and circulating cortisol levels: The intensity threshold effect. J Endocrinol Invest. 2014;14:350-353.

[29] Silverman MN, Sternberg EM. Glucocorticoid regulation of inflammation and its functional correlates: From HPA axis to glucocorticoid receptor dysfunction. Ann NY Acad Sci. 2012;1261:55-63. https://doi.org/10.1111/j.17496632.2012.06633.x

[30] Liao YH, Sung YC, Chou CC, Chen CY. Eight-week training cessation suppresses physiological stress but rapidly impairs health metabolic profiles and aerobic capacity in elite taekwondo athletes. PLoS One. 2016;11:e0160167. https://doi.org/10.1371/journal.pone.0160167

[31] Borresen J, Lambert MI. Autonomic control of heart rate during and after exercise: Measurements and implications for monitoring training status. Sport Med. 2008;38:633-646.

[32] Mulukutla BC, Yongky A, Le T, Mashek DG, Hu WS. Regulation of glucose metabolism - A perspective from cell bioprocessing. Trends Biotechnol. 2016;34:638-651. https://doi.org/10.1016/j.tibtech.2016.04.012

[33] González-Haro C. Maximal fat oxidation rate and cross-over point with respect to lactate thresholds do not have good agreement. Int J Sports Med. 2011;32:379-385. https://doi.org/10.1055/s-0031-1271763

[34] Alpert NR. Lactate production and removal and the regulation of metabolism. Ann NY Acad Sci. 1965;119: 995-1012. https://doi.org/10.1111/j.1749-6632.1965.tb47457.x

[35] Schurr A. Lactate, not pyruvate, is the end product of glucose metabolism via glycolysis in carbohydrate (InTech, 2017). https://doi.org/10.5772/66699

[36] Müller P, Duderstadt Y, Lessmann V, Müller NG. Lactate and BDNF: Key mediators of exercise induced neuroplasticity? J Clin Med. 2020;9:1136. https://doi.org/10.3390/jcm9041136

[37] Fernandez-Marcos PJ, Auwerx J. Regulation of PGC-1 $\alpha$, a nodal regulator of mitochondrial biogenesis. Am J Clin Nutr. 2011;93. https://doi.org/10.3945/ajcn.110.001917

[38] Tanaka T, Nishimura A, Nishiyama K, Goto T, Numaga-Tomita T, Nishida M. Mitochondrial dynamics in exercise physiology. Pflugers Arc Eur J Physiol. 2020; 472:137-153. https://doi.org/10.1016/j.redox.2019.101167

[39] Liu J, Lu W, Shi B, Klein S, Su X. Peroxisomal regulation of redox homeostasis and adipocyte metabolism. Redox Biology. 2019;24. https://doi.org/10.1016/j.redox.2019.101167

[40] Kadlec AO, Barnes C, Durand MJ, Gutterman DD. Microvascular adaptations to exercise: Protective effect of PGC-1 Alpha. Am J Hypertens. 2018;31:240-246. https://doi.org/10.1093/ajh/hpx162

[41] Ma EB, Sahar NE, Jeong M, Huh JY. Irisin exerts inhibitory effect on adipogenesis through regulation of Wnt signaling. Front Physiol. 2019;10:1-10. https://doi.org/10.3389/fphys.2019.01085

[42] Gomarasca M, Banfi G, Lombardi G. Myokines: The endocrine coupling of skeletal muscle and bone. Advances in Clinical Chemistry. 2020;94. https://doi.org/10.1016/bs.acc.2019.07.010

[43] Kim H, et al. Irisin mediates effects on bone and fat via $\alpha$ V integrin receptors. Cell. 2018;175:1756-1768.e17.

[44] Wrann CD, White JP, Salogiannnis J, et al. Exercise induces hippocampal BDNF through a PGC-1 $\alpha /$ FNDC5 pathway. Cell Metab. 2013;18: 649-659. https://doi.org/10.1016/j.cmet.2013.09.008 
[45] Maass A, Duzel S, Brigadski T, et al. Relationships of peripheral IGF-1, VEGF and BDNF levels to exercise-related changes in memory, hippocampal perfusion and volumes in older adults. Neuroimage. 2016;131:142-154. https:// doi.org/10.1016/j.neuroimage.2015.10.084

[46] Jodeiri Farshbaf M, Ghaedi K, Megraw TL, et al. Does PGC1 $\alpha / F N D C 5 / B D N F$ elicit the beneficial effects of exercise on neurodegenerative disorders? NeuroMolecular Med. 2016;18:1-15. https://doi.org/10.1007/s12017-015-8370-x

[47] Huang SH, Wang J, Sui W-H, et al. BDNF-dependent recycling facilitates TrkB translocation to postsynaptic density during LTP via a Rab11-dependent pathway. J Neurosci. 2013;33:9214-9230. https://doi.org/10.1523/ JNEUROSCI.3256-12.2013

[48] Leßmann V, Brigadski T. Mechanisms, locations, and kinetics of synaptic BDNF secretion: An update. Neurosci Res. 2009;65:11-22. https://doi.org/10.1016/j.neures.2009.06.004

[49] Cunha C, Brambilla R, Thomas KL. A simple role for BDNF in learning and memory? Front Mol Neurosci. 2010;3. https://doi.org/10.3389/neuro.02.001.2010

[50] Seifert T, Brassard P, Wissenberg M, et al. Endurance training enhances BDNF release from the human brain. Am J Physiol Integr Comp Physiol. 2010;298:R372-R377. https://doi.org/10.1152/ajpregu.00525.2009

[51] Rasmussen P, Brassard P, Adser H, et al. Evidence for a release of brain-derived neurotrophic factor from the brain during exercise. Exp. Physiol. 2009;94:1062-1069. https://doi.org/10.1113/expphysiol.2009.048512

[52] Herold F, Müller P, Gronwald T, Müller NG. Dose-response matters! - A perspective on the exercise prescription in exercise-cognition research. Front Psychol. 2019;10:1-17. https://doi.org/10.3389/fpsyg.2019.02338

[53] Young EA, Abelson J, Lightman SL. Cortisol pulsatility and its role in stress regulation and health. Front. Neuroendocrinol. 2004;25:69-76. https://doi.org/10.1016/j.yfrne.2004.07.001

[54] Viru A, Viru M. Cortisol - Essential adaptation hormone in exercise. Int J Sports Med. 2004;25:461-464. https://doi. org/10.1055/s-2004-821068

[55] Stieg MR, Sievers C, Farr O, Stalla GK, Mantzoros CS. Leptin: A hormone linking activation of neuroendocrine axes with neuropathology. Psychoneuroendocrinology. 2015;51:47-57. https://doi.org/10.1016/j.psyneuen.2014.09.004

[56] Perseghin G, Lattuada G, Ragogna F, et al. Free leptin index and thyroid function in male highly trained athletes. Eur J Endocrinol. 2009;161: 871-876. https://doi.org/10.1530/EJE-09-0569

[57] Fedewa MV, Hathaway ED, Ward-Ritacco CL, Williams TD, Dobbs WC. The effect of chronic exercise training on leptin A systematic review and meta-analysis of randomized controlled trials. Sport Med. 2018;48:1437-1450. https://doi. org/10.1007/s40279-018-0897-1

[58] Bobbert T, Mai K, Brechtel HM, et al. Leptin and endocrine Pparameters in marathon runners. Int J Sports Med. 2012;33:244-248. https://doi.org/10.1055/s-0031-1291251

[59] Bi X, et al. Does circulating leptin play a role in energy expenditure? Nutrition. 2018;60:6-10. https://doi.org/10.1016/j. nut.2018.08.015

[60] Tomlinson JW, Walker EA, Bujalska IJ, et al. 11ß-Hydroxysteroid dehydrogenase type 1: A tissue-specific regulator of glucocorticoid response. Endocrine Rev. 2004;25:831-866. https://doi.org/10.1210/er.2003-0031

[61] Benbaibeche H, Bounihi A, Koceir EA. Leptin level as a biomarker of uncontrolled eating in obesity and overweight. Ir. J. Med. Sci. 2020 https://doi.org/10.1007/s11845-020-02316-1

[62] Wang $\mathrm{P}$, Loh $\mathrm{KH}, \mathrm{Wu} \mathrm{M}$, et al. A leptin-BDNF pathway regulating sympathetic innervation of adipose tissue. Nature. 2020;583: 839-844. https://doi.org/10.1038/s41586-020-2527-y

[63] Garza JC, Guo M, Zhang W, Lu XY. Leptin restores adult hippocampal neurogenesis in a chronic unpredictable stress model of depression and reverses glucocorticoid-induced inhibition of GSK-3B/B-catenin signaling. Mol Psychiatry. 2012;17:790-808. https://doi.org/10.1038/mp.2011.161

[64] Hewagalamulage SD, Lee TK, Clarke IJ, Henry BA. Stress, cortisol, and obesity: A role for cortisol responsiveness in identifying individuals prone to obesity. Domest Anim Endocrinol. 2016;56:S112-S120. https://doi.org/10.1016/j. domaniend.2016.03.004

[65] Canet G, Chevallier N, Zussy C, Desrumaux C, Givalois L. Central role of glucocorticoid receptors in Alzheimer's disease and depression. Frontiers in Neuroscience. 2018;12:739. https://doi.org/10.3389/fnins.2018.00739

[66] de Kloet ER, Otte C, Kumsta R, et al. Stress and Depression: a Crucial Role of the Mineralocorticoid Receptor. J Neuroendocrinol. 2016;28. https://doi.org/10.1111/jne.12379

[67] Juruena MF. Early-life stress and HPA axis trigger recurrent adulthood depression. Epilepsy and Behavior. 2014;38: 148-159. https://doi.org/10.1016/j.yebeh.2013.10.020

[68] de Assis GG, Gasanov EV. BDNF and Cortisol integrative system - Plasticity vs. degeneration: Implications of the Val66Met polymorphism. Frontiers in Neuroendocrinology. 2019;55:100784. https://doi.org/10.1016/j. yfrne.2019.100784

[69] Boström P, Wu J, Jedrychowski MP, et al. A PGC1- $\alpha$-dependent myokine that drives brown-fat-like development of white fat and thermogenesis. Nature. 2012;481:463-468. https://doi.org/10.1038/nature10777

[70] Siteneski A, Cunha MP, Lieberknecht V, et al. Central irisin administration affords antidepressant-like effect and modulates neuroplasticity-related genes in the hippocampus and prefrontal cortex of mice. Prog NeuroPsychopharmacology Biol Psychiatry. 2018;84:294-303. https://doi.org/10.1016/j.pnpbp.2018.03.004

[71] de Assis GG, de Almondes KM. Exercise-dependent BDNF as a modulatory factor for the executive processing of individuals in course of cognitive decline. A systematic review. Front Psychol. 2017;8:1-8. https://doi.org/10.3389/ fpsyg.2017.00584

[72] Raichlen DA, Polk JD. Linking brains and brawn: exercise and the evolution of human neurobiology. Proc R Soc B Biol Sci. 2012;280:20122250. https://doi.org/10.1098/rspb.2012.2250

[73] Hill T, Polk JD. BDNF, endurance activity, and mechanisms underlying the evolution of hominin brains. Am J Phys Anthropol. 2019;168:47-62. https://doi.org/10.1002/ajpa.23762

[74] von Bohlen und Halbach O, von Bohlen und Halbach V. BDNF effects on dendritic spine morphology and hippocampal function. Cell and Tissue Research. 2018;373:729-741. https://doi.org/10.1007/s00441-017-2782-x 
[75] Archer T, Josefsson T, Lindwall M. Effects of physical exercise on depressive symptoms and biomarkers in depression. CNS Neurol. Disord. - Drug Targets. 2015;13:640-1653. https://doi.org/10.2174/1871527313666141130203245

[76] Sartori CR, Vieira AS, Ferraria EM, Langone F, Tongiorgi E, Parada CA. The antidepressive effect of the physical exercise correlates with increased levels of mature BDNF, and proBDNF proteolytic cleavage-related genes, p11 and tPA. Neuroscience. 2011;180:9-18. https://doi.org/10.1016/j.neuroscience.2011.02.055 